\title{
Genetic Diversity Analysis of Lates calcarifer (Bloch 1790) in Captive and Wild Populations Using RAPD Markers
}

\author{
Muthusamy RAJASEKAR, Muthusamy THANGARAJ*, Thathiredypalli R. \\ BARATHKUMAR, Jayachandran SUBBURAJ, Kaliyan MUTHAZHAGAN \\ Annamalai University, Centre of Advanced Study in Marine Biology, Faculty of Marine Sciences, \\ Parangipettai, Tamil Nadu, 608 502, India; coralholder@yahoo.com (*correspondingauthor)
}

\begin{abstract}
Lates calcarifer (Bloch 1790) is one of the major economically important cultivable fish species in India. In this study, three populations of $L$. calcarifer was selected to assess the genetic diversity. Of which, two wild (Mudaslodai, Muthupettai) and one captive (Mutukadu) population. The genetic diversity of three populations of this species was studied using Random Amplified Polymorphic DNA (RAPD) markers. Ten random primers were used for the assessment of their genetic diversity and construction of the dendrogram. A total of 589 scorable bands were obtained, $93.12 \%$ of them were polymorphic. The Nei's gene diversity $(\mathrm{H})$ of two wild populations were more $(0.0504 \pm 0.0670$ and $0.0519 \pm 0.0953)$ than the captive population $(0.0489 \pm 0.0850)$. The clustering pattern obtained by UPGMA method emphasized the wild populations were clustered in one clade and captive population was deviated into another clade. This study proved that RAPD analysis has the ability to discriminate $L$. calcarifer populations. Further molecular studies, comprising a higher number of molecular tools are still required to precisely evaluate the genetic structure of all seabass populations along the Indian coast.
\end{abstract}

Keywords: captive and wild populations, genetic diversity, Lates calcarifer, polymorphism, RAPD markers

\section{Introduction}

Lates calcarifer (Bloch 1790) is commonly known as Asian seabass in Asia and barramundi in Australia. This species has been successfully farmed in several Asian countries like Thailand, Singapore, Malaysia, Indonesia, Taiwan, Brunei, Hong Kong, China, Saudi Arabia and Australia (Chou and Lee, 1997; Zhu et al., 2006a). Currently, seabass is an increasingly important tropical aquaculture species in Asia-Pacific region and it is inevitable to commencement of various breeding programmes for this species, (Wang et al., 2008). Knowledge of genetic variation in seabass is important for the construction of appropriate breeding programs and for a good management of these species. Generally, small effective population size and unmonitored selective breeding programs are the major causes for the loss of genetic diversity in cultured species (Hansen et al., 2001).

A number of studies reported that cultured fish stocks showed lower genetic diversity than wild populations (Norris et al., 1999). Understanding the genetic diversity of wild populations is needed for setting up a founder population with high allelic and gene diversity, and in turn that is the first step toward successful selection of a hatchery (Norris et al., 1999). Regarding seabass, there is limited number of works have been done in genetic variation in India and worldwide. In particular, the study about genetic relationship of Australian populations (L. calcarifer) with mitochondrial DNA polymorphism (Chenoweth et al., 1998; Doupe et al., 1999), and only one broodstock in Singapore which was analyzed with eight micosatellite markers (Yue et al., 2002). Availability of more such genetic data could be very useful for stock management, selective breeding programs and sustainable use of wild resources (Kim et al., 2004; Liu and Cordes, 2004; Norris et al., 1999).

Nowadays, many molecular methods are available for studying various aspects of wild populations, captive broodstocks and interactions between wild and cultured fish stocks (Yue et al., 2009). The choice of markers for particular applications is not also straightforward and mostly depends on the experience of the investigators, laboratory facilities and available fund. RAPD is a random amplification of anonymous loci by PCR, has several advantages and has been quite widely employed in fisheries studies. The method is simple, rapid and cheap, only a small amount of DNA is required no need for molecular hybridization and most importantly, no prior knowledge of the genetic make-up of the organism in question is required (Hadrys et al., 1992). It is a simple and rapid technique used for population genetic studies (Hardys et al., 1992) to determine genetic diversity and to identify useful genetic markers at different taxonomic levels of various marine organisms (Heipel et al., 1998; Klinbunga et al., 2000; Tassanakajon et al., 1998). RAPDs have gained considerable attention particularly in population genetics (Lu and Rank, 1996), species and subspecies identification (Bardakci and Skibinski, 1994), phylogenetics, linkage 
34

group identification, chromosome and genome mapping, analysis of interspecific gene flow and hybrid speciation, and analysis of mixed genome samples (Hadrys et al., 1992).

In the present study, random primers were used to develop population specific markers and observe the genetic diversity information about the wild (Muthupettai and Mudasalodai) and one captive (Muttukadu) population of seabass. The findings of this present work will be helpful in future genetic selection of founder population for successful breeding programs

\section{Materials and methods}

\section{Sample collection and DNA extraction}

Seabass fin clips were collected from three stations namely Mudasalodai, Muthupettai (Wild) and Muttukadu (Captive) in southeast coast of India (Fig. 1). Fifteen samples were collected from each site and the tissue samples were stored in 95\% ethanol. Genomic DNA was extracted from stored fin clips by the standard protocol (Sambrook et al., 1989). DNA samples from individuals of each species was diluted to about $25 \mathrm{ng} / \mu$ lwith deionized distilled water and used for PCR amplification.

\section{Polymerase Chain Reaction}

Ten commercially available decamer random primers (An1-An10) (Tab. 1) from Chromous Biotech Pvt Ltd (Bangalore, India) were used for this study. The amplification reaction was carried out in a $25 \mu \mathrm{l}$ reaction volume containing $10 \mathrm{mM}$ Tris- $\mathrm{HCl}, \mathrm{pH} 8.5,50 \mathrm{mM} \mathrm{KCl}$, $2.5 \mathrm{mM} \mathrm{MgCl}_{2}, 0.001 \%$ gelatin, $100 \mu \mathrm{M}$ each of dATP, dCTP, dGTP, and dTTP, $0.2 \mu \mathrm{M}$ of each primer, $1 \mathrm{U}$ of Taq DNA polymerase (Bangalore Genei, India) and $25 \mathrm{ng}$ of genomic DNA. RAPD-PCR was performed in a thermocycler (Lark, India) for 40 cycles consisting of denaturation at $94^{\circ} \mathrm{C}$ for 30 seconds, annealing at $35^{\circ} \mathrm{C}$ for 30
Tab. 1. The details of the RAPD primer used in this study

\begin{tabular}{cccc}
\hline Sl. No & Primer name & Sequence & $\mathrm{Ta}\left({ }^{\circ} \mathrm{C}\right)$ \\
\hline 1 & An1 & GATGACCGCC & 35 \\
2 & An2 & GGCACCATTC & 35 \\
3 & An3 & GGTGCGCCTT & 35 \\
4 & An4 & GTCGCCGTCT & 35 \\
5 & An5 & GGCATGACCT & 35 \\
6 & An6 & GTGCCCGTTA & 35 \\
7 & An7 & TCCCACGCAG & 35 \\
8 & An8 & TGAGCGGACA & 35 \\
9 & An9 & TGCGCTCCAT & 35 \\
10 & An10 & TGTCGTGGTC & 35 \\
\hline
\end{tabular}

seconds, and extension at $72^{\circ} \mathrm{C}$ for 60 seconds. The final extension was carried out at the same temperature for 5 minutes. The resulting products were electrophoretically analyzed through $1.5 \%$ agarose gels, stained with ethidium bromide, and visualized using a UV transilluminator. Subsequently the gel was photographed using a gel documentation system (Lark, India).

\section{Data analysis}

Sizes of RAPD bands were determined by comparison with a $100 \mathrm{bp}$ ladder and genetic similarity/distance between the three species was estimated using PopGene Software (Version 1.31, Yeh et al., 1999). Nei and Li's (1979) genetic similarity (GS) among the three populations was computed and converted by PopGene into genetic distance (GD), according to Hillis and Mortiz's (1990) formula, GD = 1-GS. The GS reflects the proportion of the bands shared between individuals and values range from (1) when present, to (0) when absent. Phylogenetic relationship based on genetic distance values generated from RAPD data among three populations were made and dendrogram was plotted, using UPGMA method (Sneath and Sokal, 1973).

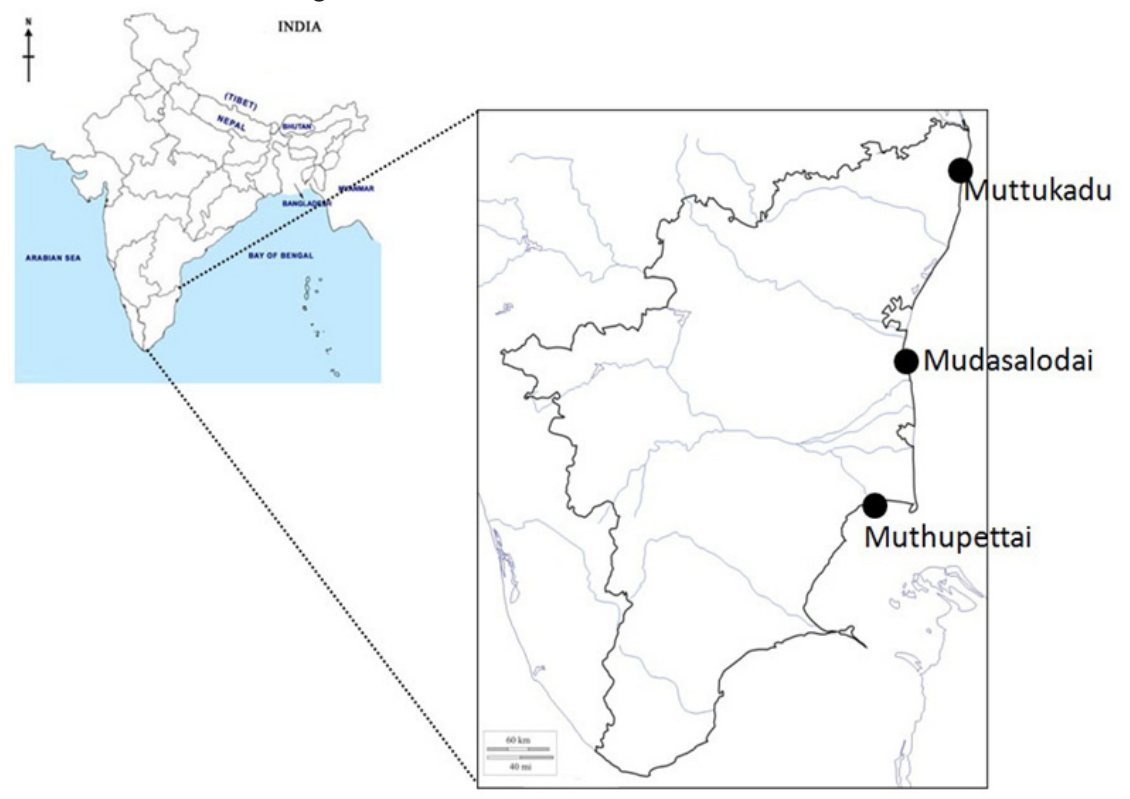

Fig. 1. Map of sample collection sites in Tamil Nadu state 


\section{Results and discussion}

Totally, 589 bands were scored by using 10 random primers in three seabass populations. Among these three populations, Muthupettai showed high number of bands (294) than the counterpart wild population, Mudasalodai (150), whereas, the captive population (Muttukadu) showed 145 bands. Number and size of the fragments produced by ten RAPD primers and molecular weight of the bands in three populations of $L$. calcarifer was give in Tab. 2. Although there was some variation observed between individuals within population but most of the bands were less variable among individuals in a population.

The genetic distance between Mudasalodai (wild) and Muttukadu (captive) was higher (0.0097) than Muthupettai (0.0063), the wild population (Tab. 3). The genetic distance between Muttukadu and Muthupettai was 0.0077 . The genetic identity was more (0.9937) between Mudasalodai and Muthupettai (wild) than Muttukadu (0.9923), the captive population. The overall observed and expected polymorphic loci of three populations of $L$. calcarifer are given in Tab. 4. The genetic diversity $(\mathrm{H})$ of two wild populations were more $(0.0504 \pm 0.0670$ and $0.0519 \pm 0.0953)$ than the captive population $(0.0489 \pm 0.0850)$. The UPGMA tree (Fig. 2) grouped the three populations into separate clusters emphasizing the distinct population status of Mudasalodai, Muthupettai and Muttukadu. Among these three populations, Mudasalodai and Muthupettai (wild) were closely related than Muttukadu (captive).

This is the first report to assess genetic variation in both wild and captive $L$. calcarifer populations of India. This present study revealed 589 polymorphic loci, indicating high level of polymorphism in three populations and supporting the suitability of RAPD markers for effectively discriminating different populations. Also this study compared the genetic variation between wild stocks and hatchery bred individuals, which might assist in formulating good management practices for increased aquaculture production.

During this investigation, the RAPD profile showed 93.12\% polymorphic loci among the three populations. As compared to previous studies, $75 \%$ of polymorphic loci were reported in three Catla catla populations (Islam et al., 2005). Barman et al. (2003) reported $45 \%$ of polymorphic loci in four Indian major carp population using RAPD primers. Islam and Alam (2004) observed 46.5\% of polymorphic loci in four different Labeo robita population. In the present study, relatively high level of genetic polymorphism was observed due to the small sampling size.

While considering the Nei's gene diversity $(\mathrm{H})$, it was high $(0.0504 \pm 0.0670$ and $0.0519 \pm 0.0953)$ in wild populations compared to the captive population (0.0489 \pm 0.0850 ). This result also coincides with previous study revealed by microsatellite marker, reported that cultured

Tab. 2. Number and size of the fragments produced by ten RAPD primers and molecular weight of bands in three populations of Lates calcarifer

\begin{tabular}{cccccc}
\hline Primer & $\begin{array}{c}\text { Total no. of } \\
\text { fragments }\end{array}$ & $\begin{array}{c}\text { No. of fragments } \\
\text { in Muthupettai } \\
\text { (wild) }\end{array}$ & $\begin{array}{c}\text { No. of fragments } \\
\text { in Mudasalodai } \\
\text { (wild) }\end{array}$ & $\begin{array}{c}\text { No of fragments } \\
\text { in Muttukadu } \\
\text { (captive) }\end{array}$ & $\begin{array}{c}\text { Size range of } \\
\text { fragments (bp) }\end{array}$ \\
\hline An1 & 10 & 2 & 4 & 4 & 21 \\
An2 & 77 & 34 & 22 & 1 & $1533-115$ \\
An3 & 41 & 25 & 15 & 28 & $1389-146$ \\
An4 & 81 & 31 & 22 & 21 & $1170-188$ \\
An5 & 68 & 33 & 14 & 25 & $1004-212$ \\
An6 & 77 & 35 & 17 & 25 & $962-144$ \\
An7 & 60 & 19 & 16 & 20 & $1069-172$ \\
An8 & 78 & 44 & 14 & - & $1177-200$ \\
An9 & 48 & 37 & 11 & - & $1309-212$ \\
An10 & 49 & 34 & 15 & 145 & $1493-204$ \\
\hline Total & 589 & 294 & 150 & - \\
\hline
\end{tabular}

Tab. 3. Genetic identity (above diagonal) and genetic distance (below diagonal) of three populations of Lates calcarifer

\begin{tabular}{cccc}
\hline Populations & $\begin{array}{c}\text { Muthupettai } \\
\text { (wild) }\end{array}$ & $\begin{array}{c}\text { Mudasalodai } \\
\text { (wild) }\end{array}$ & $\begin{array}{c}\text { Muttukadu } \\
\text { (captive) }\end{array}$ \\
\hline $\begin{array}{c}\text { Muthupettai } \\
\text { (wild) }\end{array}$ & ****** & 0.9937 & 0.9923 \\
$\begin{array}{c}\text { Mudasalodai } \\
\text { (wild) }\end{array}$ & 0.0063 & ${ }^{* * * * * *}$ & 0.9903 \\
$\begin{array}{c}\text { Muttukadu } \\
\text { (captive) }\end{array}$ & 0.0077 & 0.0097 & ${ }^{* * * * * *}$ \\
\hline
\end{tabular}

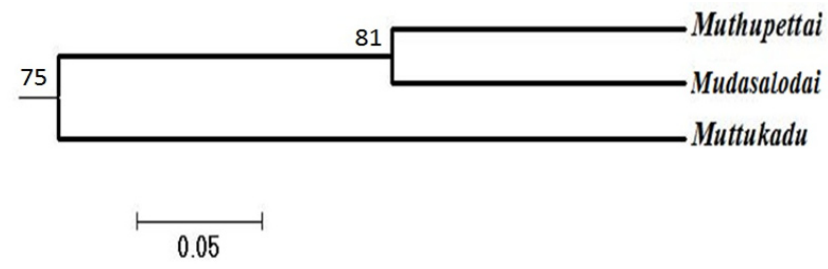

Fig. 2. UPGMA tree (1000 replications) generated from RAPD data of the three populations of Lates calcarifer (scale indicates genetic distance) 
Tab. 4. Overall observed number of alleles $(\mathrm{Na})$, Effective number of alleles $(\mathrm{Ne})$, gene diversity $(\mathrm{H})$, Shannon's Information index (I), Number of polymorphic loci ( Np) and Percentage of polymorphic loci (Pp) in three populations of Lates calcarifer

\begin{tabular}{ccccccc}
\hline Populations & $\mathrm{Na}$ & $\mathrm{Ne}$ & $\mathrm{H}$ & $\mathrm{I}$ & $\mathrm{Np}$ & $\mathrm{Pp}(\%)$ \\
\hline $\begin{array}{c}\text { Muthupettai } \\
\text { (wild) }\end{array}$ & $1.5008 \pm 0.5004$ & $1.0594 \pm 0.0915$ & $0.0504 \pm 0.0670$ & $0.1009 \pm 0.1191$ & 331 & 50.08 \\
$\begin{array}{c}\text { Mudasalodai } \\
\text { (wild) }\end{array}$ & $1.2481 \pm 0.4322$ & $1.0680 \pm 0.1343$ & $0.0519 \pm 0.0953$ & $0.0898 \pm 0.1604$ & 164 & 20.01 \\
$\begin{array}{c}\text { Muttukadu } \\
\text { (captive) }\end{array}$ & $1.3041 \pm 0.4604$ & $1.0621 \pm 0.1212$ & $0.0489 \pm 0.0850$ & $0.0890 \pm 0.1452$ & 201 & 23.03 \\
Overall & $2.0000 \pm 0.0000$ & $1.0599 \pm 0.0536$ & $0.0546 \pm 0.0390$ & $0.1239 \pm 0.0624$ & - & - \\
\hline
\end{tabular}

fish stocks of $L$. calcarifer showed lower genetic diversity than wild populations. Frost et al. (2006) illustrate that hatchery management practices have the potential to significantly impact on the retention of genetic diversity in this species. Other results also reveal high levels of polymorphism in Atlantic salmon using microsatellite markers in which farmed salmon showed less genetic variability than wild salmon in terms of allelic diversity but not necessarily in terms of overall heterozygosity (Norris et al., 1999). This reduction may be the effect of small effective population size, low genetic variation of founder populations, and low reproductive success of some founders.

Nei's genetic identities in wild populations were high ( 0.9937$)$ as compared with captive ( 0.9903 between Muttukadu and Mudasalodai; 0.9923 between Muttukadu and Muthupettai). Nei's genetic distance was also low (0.0063) between wild populations compared to distance between wild and captive population ( 0.0077 between Muttukadu and Muthupettai; 0.0097 between Muttukadu and $\mathrm{Mu}-$ dasalodai). This result coincides with the previous study in which farmed population were most similar when compared to wild populations of Atlantic salmon, Salmo salar (Norris et al., 1999). Xu et al. (2001) also observed same type of result in the black tiger shrimp, Penaeus monodon, where the genetic diversity was more in Philippines wild populations than captive population and the genetic distance was also more between the wild populations than the captive one.

The clustering pattern obtained by UPGMA method wherein wild populations were clustered in one clade and captive population was separated in another clade. The similar clustering pattern was obtained with other RAPD profiling analysis study on three wild populations of Catla carp, Catla catla and one hatchery reared population of Bangladesh which form separate clusters for wild and hatchery reared carps (Khan et al., 2009). In Brycon opalinus, the Brazilian freshwater fish species, Hilsdorf et al. (2002) showed the genetic diversity was more than the captive populations using mitochondrial markers. The dendogram analyses of microsatellite studies on Brycon opalinus showed a regional structure grouping individuals of closer regions (Barroso et al., 2005). They also reported that all six wild populations and one captive population was deviated significantly to HWE showing deficit of heterozygote and they suggested that it was due to anthropogenic habitat deterioration and fragmentation.

\section{Conclusions}

Despite some limitations, the RAPD analysis can be used effectively for initial assessment of genetic variation among fish species, particularly like economically important cultivable fishes. The present study represents a first step towards the generation of RAPD markers for population identification and assessment of genetic diversity of captive and wild populations of seabass. Further molecular studies, comprising a higher number of molecular tools are still required to precisely evaluate the genetic structure of seabass along the Indian coast.

\section{References}

Bardakci F, Skibinski DOF (1994). Application of the RAPD technique in tilapia fish: species and subspecies identification. Heredity 73:117-123.

Barman H, Barat A, Bharat M, Banerjee Y, Meher P, Reddy P, Jana $R$ (2003). Genetic variation between four species of Indian major carps as revealed by random amplified polymorphic DNA assay. Aquaculture 217:115-123.

Barroso RMT, Hilsdorf AWS, Moreira HLM, Cabello PH, Traub-Cseko YM (2005). Genetic diversity of wild and cultured populations of Brycon opalinus (Cuvier, 1819) (Characiforme, Characidae, Bryconiae) using microsatellites. Aquaculture 247:51-65.

Chenoweth SF, Hughes JM, Keenan CP, Lavery S (1998). Concordance between dispersal and mitochondrial gene flow: isolation by distance in a tropical teleost, Lates calcarifer (Australian barramundi). Heredity 80:187-197.

Chou R, Lee HB (1997). Commercial marine fish farming in Singapore. Aqua Res 28:767-776.

Doupe RG, Horwitz P, Lymbery AJ (1999). Mitochondrial genealogy of Western Australian barramundi: applications of inbreeding coefficients and coalescent analysis for separating temporal population processes. J Fish Biol 54:1197-1209.

Frost LA, Evans BS, Jerry DR (2006). Loss of genetic diversity due to hatchery culture practices in barramundi (Lates calcarifer). Aquaculture 261:1056-1064. 
Hadrys H, Balick M, Schierwater B (1992). Applications of random amplified polymorphic DNA (RAPD) in molecular ecology. Molec Ecol 1:55-63.

Hansen MM, Ruzzante DE, Nielsen EE, Mensberg KLD (2001. Brown trout (Salmotrutta) stocking impact assessment using microsatellite DNA markers. Ecol App 11:148-160.

Heipel DA, Bishop JDD, Brand AR, Thorpe JP (1998). Population genetic differentiation of the great scallop Pecten maximusin western Britain investigated by randomly amplified polymorphic DNA. Mar Ecol Prog Ser 162:163-171.

Hillis DM, Moritz C (1990). An overview of applications of molecular systematics, 502-515 p. In: Hillis DM, Moritz C (Eds.). Molecular systematics. Sinauer Associates Sunderland, Massachusetts.

Hilsdorf AW, Espin AMA, Krieger MH, Krieger JE (2002). Mitochondrial DNA diversity in wild and captivity population of Brycon opalinus (Cuvier, 1819) (Characiforme, Characidae, Bryconiae) in the Paraı'ba do Sul Basin, Brazil. Aquaculture 214:81-91.

Islam MS, Alam MA (2004). Randomly amplified polymorphic DNA analysis of four different populations of the Indian major carp, Labeo rohita (Hamilton). J App Ichthyol 20:407-412.

Islam MS, Ahmed ASI, Azam MS, Alam MS (2005). Genetic analysis of three river populations of Catla catla (Hamilton) using randomly amplified polymorphic DNA markers. Asian-Aust J An Sci 18:453-457.

Khan, Zakiur R, Mukhlesur RK, Shahidul I, Alam S (2009). Genetic variation of wild and hatchery populations of the catla Indian major carp ( Catla catla Hamilton 1822: Cypriniformes, Cyprinidae) revealed by RAPD markers. Gene Molec Biol 32:197-201.

Kim JE, Withler RE, Ritland C, Cheng KM (2004). Genetic variation within and between domesticated Chinook salmon, Oncorhynchus tshawytscha, strains and their progenitor populations. En Biol Fish 69:371-378.

Klinbunga S, Ampayup P, Tassanakajon A, Jarayabhand P, Yoosukh W (2000). Development of species-specific markers of the tropical oyster (Crassostreabelcheri) in Thailand. Mar Biotech 2:476-484.

Liu ZJ, Cordes JF (2004). DNA marker technologies and their applications in aquaculture genetics. Aquaculture 238:1-37.

Lu R, Rank GH (1996). Use of RAPD analyses to estimate population genetic parameters in the alfalfa leaf-cutting bee, Megachilero tundata. Genome 39:655-663.
Nei M (1978). Estimation of Average hetrozygosity and genetic distance from a small number of individuals. Genetics 89:583-590.

Nei M, Li WS (1979). Mathematical model for studying genetic variation in terms of restriction endonucleases. PNAS U.S.A. 76:5269-5273.

Norris AT, Bradley DG, Cunningham EP (1999). Microsatellite genetic variation between and within farmed and wild Atlantic salmon (Salmo salar) populations. Aquaculture 180:247-264.

Sneath PHA, Sokal RR (1973). Numerical taxonomy. WH Freeman and Co., San Francisco, CA, 573 p.

Sambrook J, Fritsch EF, Maniatis T (1989). Molecular cloning: A laboratory manual, $2^{\text {nd }}$ Edn. Cold Spring Harbor Laboratory Press, Cold Spring Harbor, New York.

Tassanakajon A, Pongsomboon S, Jarayabhand P, Klinbunga S, Boonsaeng V (1998). Genetic structure in wild seabass stocks using novel polymorphic microsatellites. Aquaculture 256:167-173.

Wang, CM, Lo LC, Zhu ZY, Lin G, Feng F, Li J, Yang WT, Tan J, Chou R, Lim HS, Orban L, Yue GH (2008). Estimating reproductive success of brooders and heritability of growth traits in Asian sea bass (Lates calcarifer) using microsatellites. Aqua Res 39: 1612-1619.

Yeh FC, Yang RC, Boyle T (1999). POPGENE 32-Version 1.31. Population genetics software.

Yue GH, Li Y, Chao TM, Chou R, Orban L (2002). Novel microsatellites from Asian sea bass (Lates calcarifer) and their application to broodstock analysis. Mar Biotech 4:503-511.

Yue GH, Zhu ZY, Lo LC, Wang CM, Lin G, Feng F, Pang HY, Li J, Gong P, Liu HM, Tan J, Chou R, Lim H, Orban L (2009). Genetic variation and population structure of Asian seabass (Lates calcarifer) in the Asia-Pacific region. Aquaculture 293:22-28.

Zhu ZY, Lin G, Lo LC, Xu YX, Renee C, Yue GH (2006). Genetic analyses of Asian seabass stocks using novel polymorphic microsatellites. Aquaculture 256:167-173.

Xu Z, Primavera JH, De la Pena LD, Pettit P, Belak J, Warren AA (2001). Genetic diversity of wild and cultured black tiger shrimp (Penaeus monodon) in the Philippines using microsatellites. Aquaculture 199:13-40. 